\title{
HOW CAN WE MEASURE SPATIAL ACCESSIBILITY OF THE TERRITORY OF POLAND?
}

\author{
TOMASZ KOMORNICKI, PIOTR ROSIK, \\ PRZEMYSŁAW ŚLESZYŃSKI, WOJCIECH POMIANOWSKI
Stanisław Leszczycki Institute of Geography and Spatial Organization
Polish Academy of Sciences
Twarda 51/55, 00-818 Warszawa, Poland
e-mail: t.komorn@twarda.pan.pl,rosik@twarda.pan.pl, psleszyn@twarda.pan.pl,wpo@twarda.pan.pl

\begin{abstract}
Accessibility is widely used term and plays an important role in many scientific fields. It determines the advantage of one location over the other. Although there are different measures and number of studies on accessibility in the world literature, there are relatively few so far in Poland at the national level. The purpose of this article is to present some results of ongoing research that have been carried out at the IGSO PAS in 2007 and 2008. The projects led to development of methods of calculating time accessibility and the multimodal potential accessibility indicator of the area of Poland. The time accessibility is measured by using the isochronic-based and distance-based accessibility measures. The multimodal potential accessibility indicator is meant to be utilized, for evaluating the possible effects of construction and modernization of the transport network that are envisaged in the EU supported operational programs. The measure may be calculated separately for carriage of goods and passengers, the 16 voivodships (provinces of Poland) and four modes of transport (road, railways, inland waterways and air).
\end{abstract}

Key words: multimodal accessibility, potential, transport infrastructure, Poland

\section{INTRODUCTION}

Spatial accessibility is very important issue for transport planning at the regional and national level. It allows to assess the degree of regional inequality in the distribution of activities (opportunities) in space. Although there are different measures, variety of approaches and number of studies on accessibility in the world literature, there are relatively few so far in Poland. Most of the Polish empirical studies concerning accessibility issue were carried out at the local or regional level with notable exam- 
ples of Taylor (1999), Ratajczak (1999) and Guzik (2003). However, so far in Poland there have been conducted relatively few accessibility studies at the national level. The works carried out in the Institute of Geography and Spatial Organization of Polish Academy of Sciences in Warsaw (IGSO PAS) by the team lead by Professor Tomasz Komornicki aim at filling the gap in the knowledge in this area. The popular methods of analysis of the accessibility are used: infrastructure-based, isochronic-based, distance-based and potential-based accessibility measures.

The purpose of this article is to present some results of ongoing research that have been carried out at the IGSO PAS in 2007 and 2008. The projects, commissioned particularly by the Ministry of Regional Development, led to development of methods of calculating time accessibility and the multimodal potential accessibility indicator of the area of Poland. The time accessibility is measured by using the isochronic-based and distance-based accessibility measures. The another method (potential accessibility) is meant to be utilized, inter alia, for evaluating the possible effects of construction and modernization of the transport network that are envisaged in the EU supported operational programs. A form of potential Hansen-type accessibility indicator is proposed. In the paper, the basic issues related to methodology and practical applications of the indicator are dealt with.

\section{METHODS}

Accessibility is widely used term and plays an important role in many scientific fields. The term "accessibility" appears on more than 86 million pages indexed by Google search engine. However, most of users do not really know its meaning. As Gould (1969, p. 64) emphasizes: "accessibility... is a slippery notion...is one of these common terms that everyone uses until faced with the problem of defining and measuring it".

One can find some explanations and attempts to define the accessibility concept in the transport geography literature. The accessibility determines the advantage of one location over the other. According to Hansen (1959) accessibility can be defined by the potential of opportunities for interaction. Ingram (1971, p. 101) treats accessibility as an "inherent characteristic (or advantage) of a place with respect to overcoming some form of spatially operating source of friction (for example, time and/or distance)". Vickerman (1974, p. 676) emphasizes that accessibility "involves a combination of two elements: location on a surface relative to suitable destinations, and the characteristics of the transport network or networks linking points on the surface". Bruinsma and Rietveld (1998, p. 500) agree that accessibility is an "attractiveness of a node in a network taking into account the mass of other nodes and the costs to reach those nodes via the network". According to Geurs and Ritsema van Eck (2001) accessibility is determined by some components: land-use component (spatial distribution of 
activities at destinations and the demand for these activities), transport component (travel time, cost or effort of travelling between the origin and destination), individual component (needs, abilities and opportunities of individual travelers) and temporal component (time restrictions of individual travelers and availability of activities at different times of the day).

There are different approaches to the methodology of measurement of accessibility. On the basis of literature survey one can identify five groups of methods:

- infrastructure-based accessibility measure-the regional infrastructure equipment is evaluated by its quantity and quality and the level of congestion; this approach is relatively widely used in national transport policy plans; however, it fails to recognize the destinations located far away from the region,

- distance-based accessibility measure (travel-cost accessibility)-distance, time or cost of travel where the activity is sought (a single destination or a set of destinations), e.g., the average or total travel time between given origin and destination points in the network (cities with the population over 500 thousand inhabitants, etc.),

- isochronic-based accessibility measure (daily accessibility)_assessment of set of destinations available in particular travel distance, time or cost from the origin, e.g., the use of isochrones (lines of equal travel distance, time or cost) for measurement of accessibility to activities in a 15,30,45,60 minutes time from the place of origin,

- potential-based (gravity-based) accessibility measure-the most popular one; accessibility is measured by the number of activities (opportunities) which can be reached in a certain distance, time or effort weighted by the travel distance, time or effort to do so; the concept of potential has been introduced by the social physics school and was applied by Stewart (1947) in a study on population distribution and devised by Hansen (1959) in the context of accessibility to opportunities; the concept of potential of interactions between the origin and the set of destinations is widely used (also in IGSO PAS) and the potential analysis has spawned a number of different approaches and models,

- person-based accessibility measure-analyzing accessibility at the individual level; this package of measures is founded in the space-time geography and includes spacetime-geography-based and utility-based accessibility measures; the models take into account the individual behaviour of the transport network user and focus on the person's ability to contribute in activities through space and time; person-based accessibility measure, although mathematically advanced and commonly used in the western countries at the micro level (e.g. in metropolitan areas), are not suitable for using at the national level due to the lack of data; for that reason, we use in the IGSO PAS first four measures which are easier to calculate and give the possibility to evaluate the ease of reaching the destinations in a certain distance, time or cost; in our models we use travel time in the distance-decay function. 


\section{LAND TRANSPORTATION ACCESSIBILITY}

The isochronic-based and distance-based approaches to accessibility were used in the project called "Strategy for Developing Civil Aviation Infrastructure in Mazovia". The project was performed at the IGSO PAS in summer and autumn of 2007, upon the commission from the Mazovian Bureau of Regional Planning. Two variants of the time accessibility to the most frequently quoted locations of the regional airports in Mazovia (Modlin, Sochaczew, Mińsk Mazowiecki, Radom) were considered, for the years 2008 and 2013 (under the assumption of realization of all the planned road construction projects, mainly the sections of the A2 motorway and S7, S8 and S17 expressroads). The variants were associated with two assumed times of transit: during peak hours and outside of peak hours. The cartographic image was constituted by the map of isochrones (Komornicki and Śleszyński 2009).

Maps of isochrones were used also in the next project called "Variant Analysis of the Land Transportation Accessibility", commissioned by the Ministry of Regional Development of Poland in summer of 2008. There were recommendations for the Committee for Space Economy and Regional Planning included in the project. The main aim of the variant analysis of the land (road and railway) transportation was first of all to measure the time accessibility to:

- particular cities (Warsaw and other big cities),

- city network (Metropolitan European Growth Areas-MEGA's 8 and MEGA's 10 on the territory of Poland: Warsaw, the Tri-City (Gdańsk-Gdynia-Sopot), Szczecin, Poznań, Łódź, Wrocław, Cracow, and the Upper Silesian Conurbation (plus Lublin and Białystok),

- voivodship and subregional cities,

- national border and border crossing points,

- airports and harbours,

- touristic regions (Pomorze Zachodnie, Pomorze Wschodnie, Mazury, Sudety, Karpaty).

Three different points of time were taken into consideration: 2008 (according to the current state of infrastructure), 2015 and 2033 (the last two, after the realization of all infrastructure projects). The forecasts for 2033 were carried out in two variants:

- according to the current plans from the Concepts of Regional Planning Policy, - based on the real domestic demand needs (our postulates).

The number of inhabitants living within the particular isochrones' range was calculated for all points of time and all variants using isochronic-based accessibility measure. Some examples of project results concerning road travel times to Warsaw in 2008 and 2033 are shown in the Figure 1. 

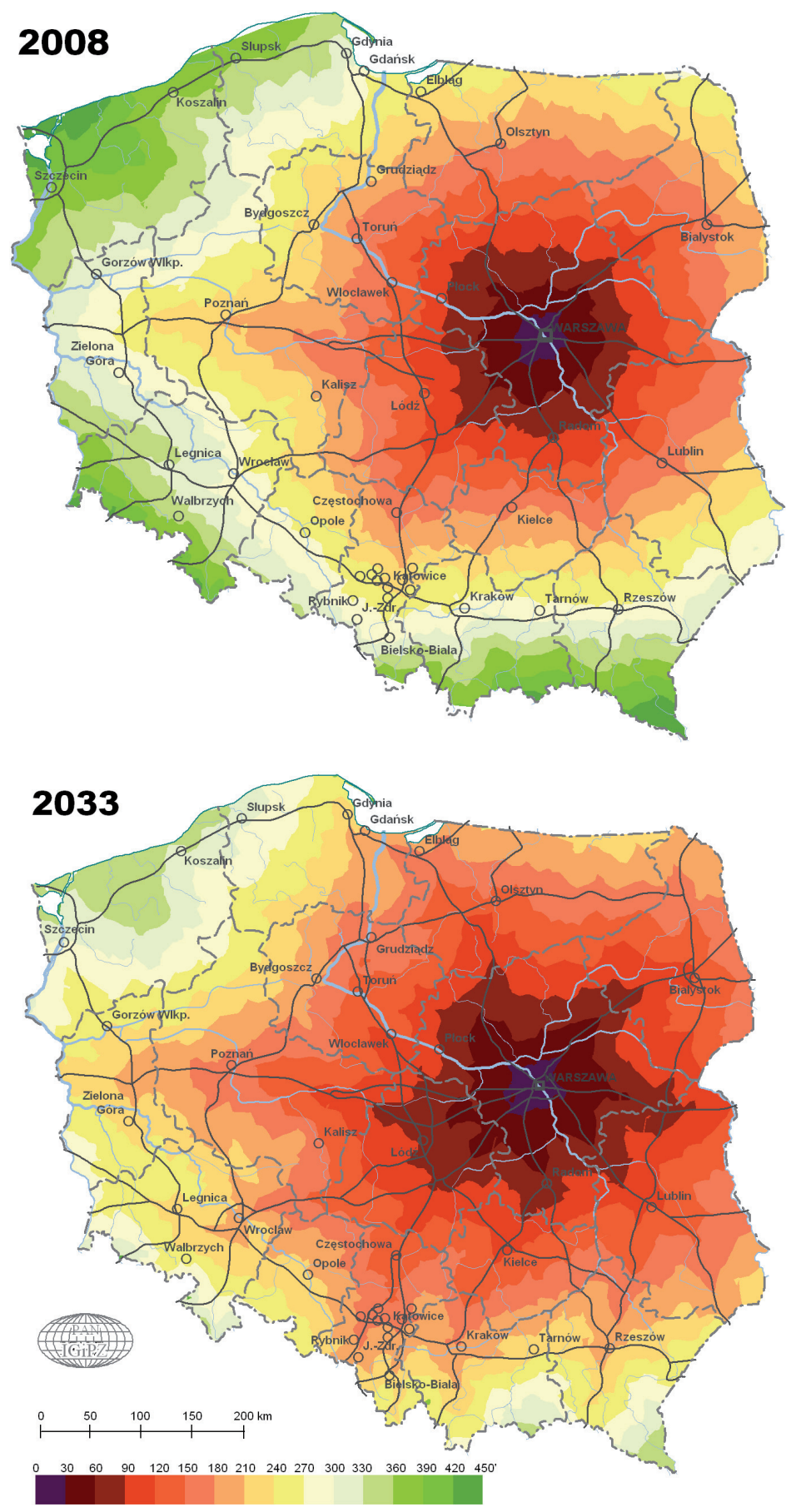

Figure 1. Road travel times to Warsaw in 2008 and 2033 (variant 1) (30 minute isochrones) Source: Figures 1-4 own elaboration. 


\section{MULTIMODAL POTENTIAL ACCESSIBILITY INDICATOR}

The infrastructure-based and potential-based accessibility measures are developed in the newest project carried out in the IGSO PAS for the Ministry of Regional Development of Poland called "Assessement of Multimodal Accessibility Indicator of the Territory of Poland". The project aims at giving opportunities for all the users of computer application, particularly for ministry officials, to evaluate the effects of infrastructure projects within Sectoral Operational Programmes. The evaluation is conducted according to the multimodal potential accessibility model.

The model is characterized by some features which are aimed at ensuring its overall comprehensiveness and effectiveness. Firstly, it takes into consideration all modes of transport occurring throughout the country (on a nationwide basis). Secondly, the detailed scale applied in the model allows to utilize it both at the national as well as regional level. Thirdly, all widely available source data are included in the calculations. Fourthly, this model is user-friendly as far as making calculations and obtaining results are concerned, since it has a special built-in software application running under the Window system.

It was assumed that the transport accessibility is a general sort of term that ought to be described by two methods:

- infrastructure-based accessibility measure to transport networks, determined on the basis of identification of a given kind of infrastructure within a region in terms of its quantity and quality,

- potential spatial accessibility measure, which has a main impact on the inter-regional comparisons.

Indicator. The potential measure was taken by way of calculating the real time of travel by means of transport recorded in the separate transportation networks. The potential accessibility is based on the power distance-decay function which produces the well-known Hansen-type indicator. The modal accessibility indicator is the sum of the mass of each other region divided by the shortest travel time to it (Hansen 1959). The closer the opportunity (mass of each other region), the more it contributes to accessibility. The larger the opportunity, the more it influences the accessibility. Hansen-type potential accessibility indicator looks as follows:

$$
A_{i m}=\sum_{j, j \neq i} \frac{M_{j}}{t_{j j m}}
$$

where: $\mathrm{A}_{i m}$ —accessibility of region $i$ by mode $m, M_{j}$ - mass of region $j, t_{i j}$ - travel time between region $i$ to region $j$ by mode $m$.

Masses. The model assumes that masses are in proportional to their position in a hierarchy of the Polish socio-economic settlement system. Separate settlement centres (at the poviat level) are of different weight when considering their significance from a socio-economic perspective. In the devised gravity model, the importance of diverse centres is determined on the basis of their weight. For the purposes of 
calculating that weight, a set of 14 socio-economic variables was taken into account, drawing distinction between passenger and goods transport. For example, for freight traffic the sold production of industry is considered as important, while for passenger traffic number of inhabitants is recognized as a valid destination. We obtained the accumulated (for both freight and passenger transport) attraction of masses of 286 nodes. This number was due to the fact that we measured accessibility at the NUTS-4 level (few poviats were aggregated to the metropolitan level).

Topological network. A graph model of settlement and transportation system was elaborated for the needs of the paper. It was presumed that the poviat (county) towns represent transportation hubs, including also a whole mass of connected land and municipal entities, as well as metropolitan areas. These data were incorporated into the matrices for calculating the time of travel by means of transport such as road, railways, air and inland waterways. In addition to the existing infrastructure, the base topological network involves also projected road and railway sections that are to be completed by 2015 , which can be then easily included into the developed model over the subsequent years as the investment projects are realized, as well as making it possible to use it for various computer simulations.

Speeds. A special model of traffic speed was developed for the needs of the road transport, utilizing, inter alia, the real speed values. For example, for road network we obtained 1400 technical nodes and 5594 sections. Each of the network sections had its own set of detailed features - the length of the section and the average speed on it. The previous research investigated the factors that influence the average speed of the vehicles. These factors are distinguished as follows: road category, population density in the road surrounding area (buffer $1 \mathrm{~km}$ ) and the lie of the land. As regards railway network, a model of traffic makes use of data concerning a maximum technical speed for individual sections - the information provided by Polskie Linie Kolejowe SA (the Polish Railway Company). As far as the air connection network is concerned, distances between different airports were measured in straight lines, and, based on the current flight timetable, the average travel times were calculated, however, taking into account only domestic connections. As for the inland waterways, a small fixed speed value at $10 \mathrm{~km}$.p.h. was set. The model gives many additional opportunities. For example, it provides users with the shortest travel path by each mode to destinations - the cities with poviat rights (Figure 2).

Modal shares. The crucial element of this model is that it allows to determine actual modal structure of transport performance (including also individual road transport) as well as to make evaluation of that structure at the voivodship level. On national level the weight (importance) of particular transport mode (road, rail, air and inland water) is measured by its share in total traffic volume. On regional level it was much more difficult to obtain the data concerning the volume of passenger and freight traffic. For that reason, the operating work was calculated, based on the data from General Directorate for National Roads and Motorways and PKP Polish Railway Lines Company. The variables introduced into the model are data 


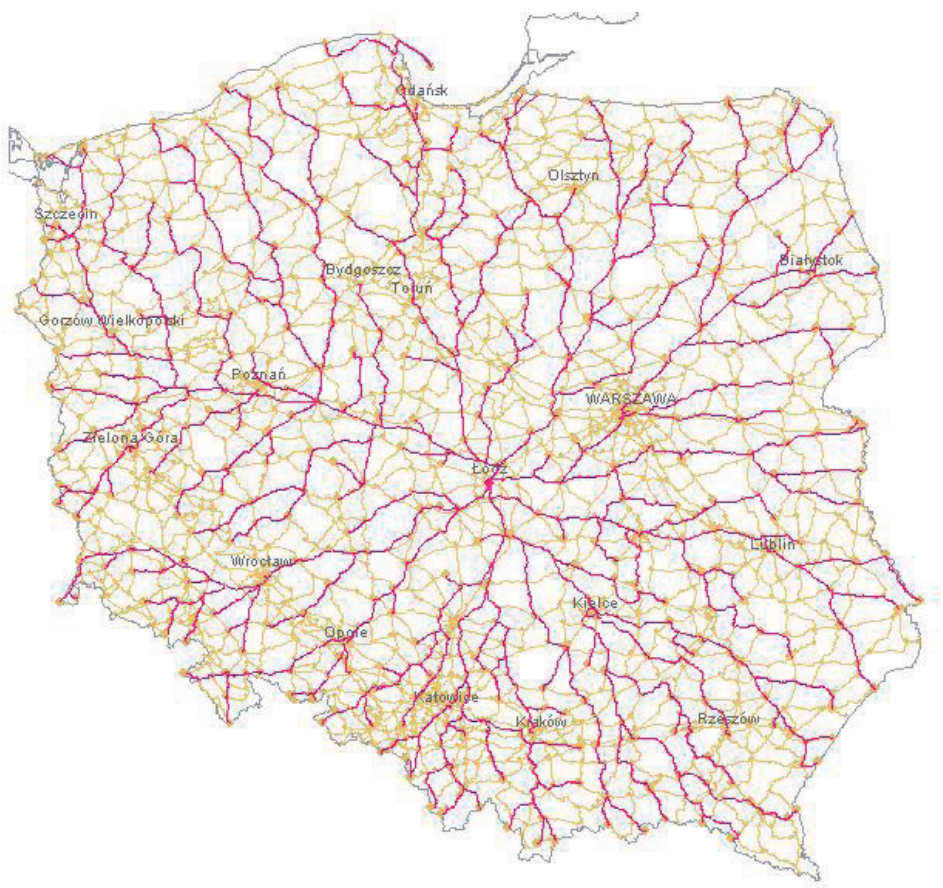

Figure 2. The shortest travel path within the road network to Łódź in 2008

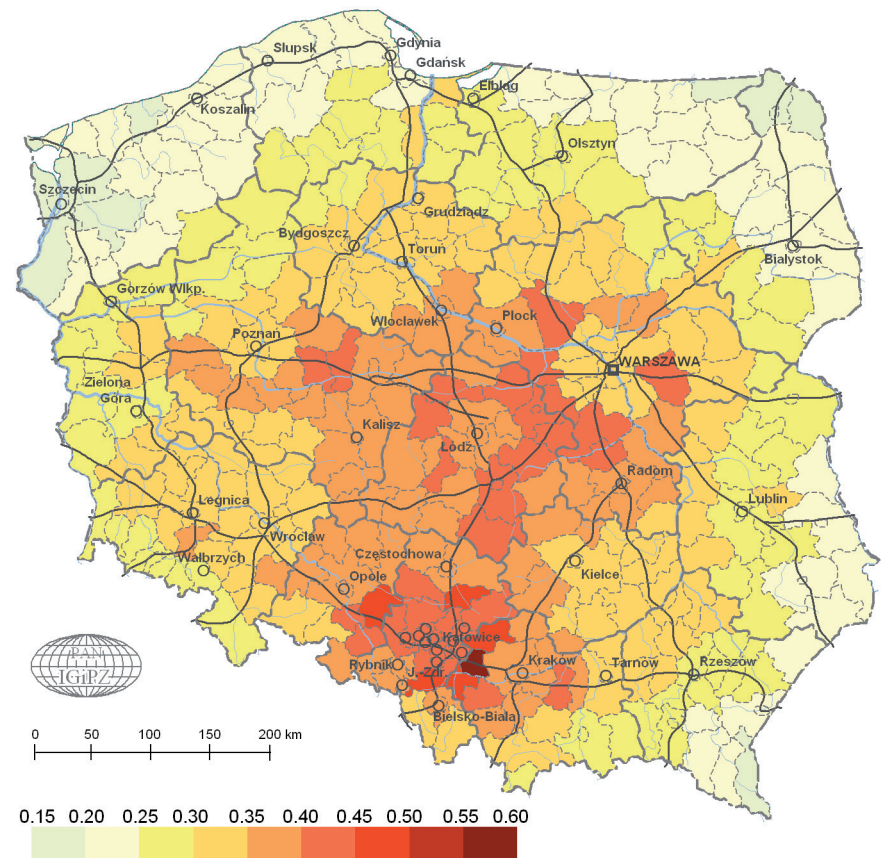

Figure 3. Potential accessibility by road in 2008 
such as, inter alia, transport performance expressed by millions of passenger-kilometres, trips by individual motorization with exclusion of urban transportation within agglomerations and other cities/towns, transport performance indicated by millions of passenger-kilometres (road and railway transport), passenger traffic in airports in total (domestic and abroad), carriage performance by millions of ton-kilometres (road and railway transport, inland waterways).

The results of potential accessibility for road passenger transport are illustrated on Figure 3.

The ministry officials who use the multimodal accessibility computer application in the Ministry of Regional Development of Poland have an opportunity to modify the socio-economic and demographic data, which lead to the changes of the attraction of masses. The application users can also change the road category or open virtually for traffic new sections of road or railway infrastructure network. They can alter the road section current status from planned to "in operation". Last but not least they can also change the modal share on the national level according to the latest data from Central Statistical Office in Poland. To sum up the opportunities of the model, it allows to modify the attraction of masses, topological network and modal shares during accessibility simulations.

As can be seen in the Figure 4, the possible positive effects for road accessibility in the cities with poviat rights when the A2 Łódź-Warsaw section is opened for traffic

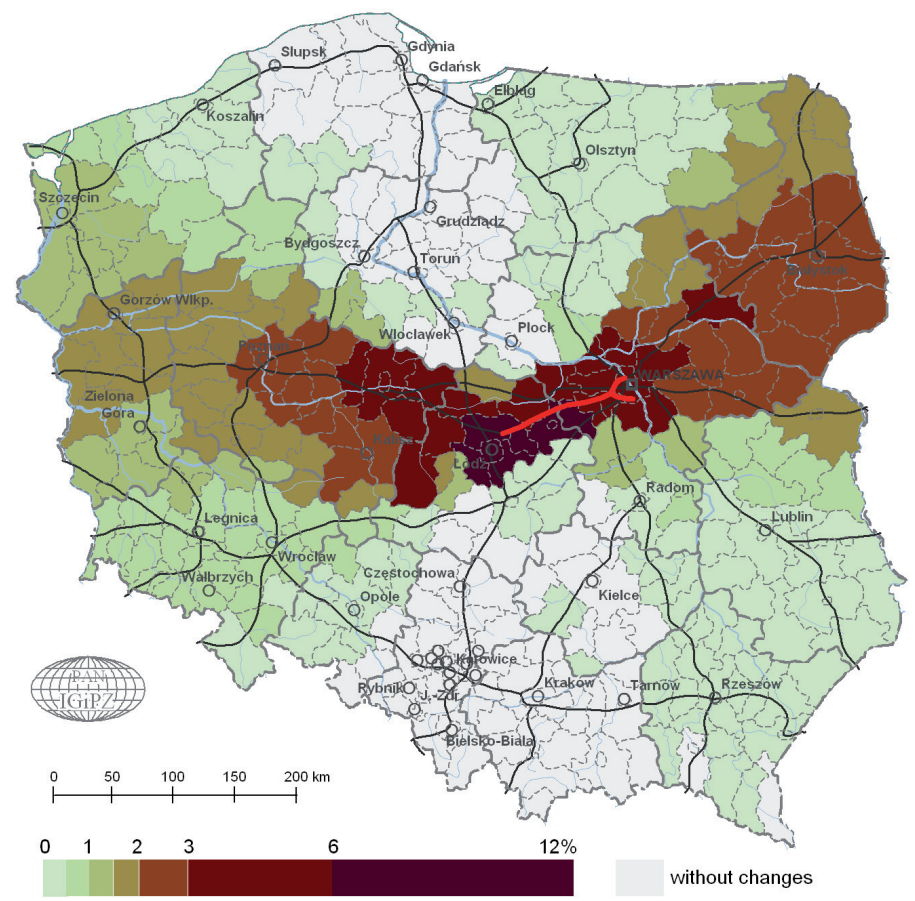

Figure 4. Accessibility change when the A2 Łódź-Warsaw section is opened for traffic (in 2012) 
(in 2012) are obvious in the poviats located in the catchment area of A2 Łódź-Warsaw section. The catchment area is the area that covers the origins of all of these trips, the part of which is the same section of road network. For example, the A2 ŁódźWarsaw motorway will be used by drivers travelling to Warsaw (or Łódź) from different origins located in the A2 Łódź-Warsaw catchment area.

As a result, the devised multimodal potential accessibility indicator is a synthetic measure of a mutual potential accessibility for the most significant national settlement centres, taking into account all the main modes of transport (proportionately to their participation in the transport performance), as well as weighing the overall level of socio-economic development. The measure may be calculated separately for carriage of goods and passengers, and, additionally, it can be made for all of the 16 voivodships (provinces of Poland) and four modes of transport (road, railways, inland waterways and air).

\section{CONCLUSIONS AND SUGGESTIONS FOR FUTURE WORKS}

The project concerning potential accessibility of the territory of Poland is on its initial stage. The main future works on content and formula of the model should be these four in this order:

1. Expansion of the computer application and the demarcation area to the international level.

2. Inclusion of the self-potential (local accessibility).

3. Addition of the possibility of modifying the structure and the form of the distancedecay function (use of exponential, power and log-logistic functions).

4. Inclusion of the traffic volume (congestion) as a variable that influences the travel time, particularly in the cities and their suburbs.

The research and analysis of potential accessibility will be carried out in several projects. Institute of Geography and Spatial Organization in Warsaw together with Slovakian partners from the Institute of Geography of Slovak Academy of Sciences in Bratislava is proceeding the research with the project called INFRAREGTUR. This project is financed from the European Regional Development Fund (Crossborder co-operation Programme Republic of Poland-Slovak Republic within the years for 2007-2013). The main aim of the project is to find infrastructural and organizational opportunities of spatial accessibility improvement in Polish-Slovakian touristic regions.

Another project concerning the potential accessibility issue is financed by the Ministry of Science and Higher Education and is called "International Land (Road and Railway) Accessibility of the poviat towns in Poland". Expected utility value of the project is a professional computer application called CENTrAc (Central European Networks-Transport and Accessibility). The project aims particularly at expanding the computer application to the international level by weighting 
the attractions (masses) located in neighbouring countries: Lithuania, Belarus, Ukraine, Slovakia, Czech Republic, Germany and Kaliningrad Oblast.

The indicator of multimodal transport accessibility is systematically updated and enhanced, and currently (autumn 2009) works on preparing its third version for Ministry of Regional Development are well under way. Also, on the basis of the expert evaluation, a monograph is being prepared to be published in the series Biuletyn KPZK PAN.

\section{REFERENCES}

Bruinsma, F. R., Rietveld, P. (1998), The accessibility of European cities: theoretical framework and comparison of approaches, Environment and Planning, 30 (3), 499-521.

Geurs, K.T. and Ritsema van Eck, J.R. (2001), Accessibility measures: review and applications, RIVM report 408505 006, National Institute of Public Health and the Environment, Bilthoven.

Gould, P. (1969), Spatial diffusion, Resource Paper, 17, Association of American Geographers, Washington, DC.

Guzik, R. (2003), Przestrzenna dostepność szkolnictwa ponadpodstawowego, Instytut Geografii i Gospodarki Przestrzennej Uniwersytetu Jagiellońskiego, Kraków.

Hansen, W.G. (1959), How accessibility shapes land-use, Journal of the American Institute of Planners, 25, 73-76.

Ingram, D.R. (1971), The concept of accessibility: a search for an operational form, Regional Studies, 5, 101-107.

Komornicki, T. and Śleszyński, P. (eds.) (2009), Studia nad lokalizacją regionalnych portów lotniczych na Mazowszu, Prace Geograficzne, 220, IGiPZ PAN, Warszawa.

Ratajczak, W. (1999), Modelowanie sieci transportowych, Bogucki Wydawnictwo Naukowe, Poznań.

Stewart, J.Q. (1947), Empirical mathematical rules concerning the distribution and equilibrium of population, Geography Review, 37, 461-485.

Taylor, Z. (1999), Przestrzenna dostępność miejsc zatrudnienia, kształcenia i usług a codzienna ruchliwość ludności wiejskiej, Prace Geograficzne, 171, IGiPZ PAN, Warszawa.

Vickerman, R.W., 1974, Accessibility, attraction, and potential: a review of some concepts and their use in determining mobility, Environment and Planning, A 6 , 675-691. 
http://rcin.org.pl 